\title{
Learning Styles and the Use of ICT in University Students within a Competency-Based Training Model
}

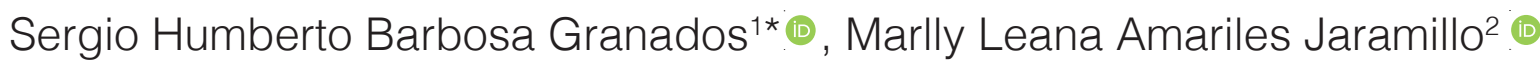 \\ Departamento de Psicología, Universidad Cooperativa de Colombia, Colombia \\ \{sergio.barbosag@campusucc.edu.co\} \\ Departamento de Diseño Crossmedia, Universidad Cooperativa de Colombia, Colombia \\ \{marlly.amarilesj@campusucc.edu.co\}
}

Received on 24 April 2018; revised on 30 April 2018; accepted on 25 May 2018; published on 15 January 2019

DOI: 10.7821/naer.2019.1.296

(c) BY-NC-ND

\begin{abstract}
The purpose of the study was to determine the learning styles (LS) and the use of Information and Communication Technologies (ICT) in university students within a competency-based training model, as well as to identify possible differences related to the frequency of use of ICT in terms of gender. A descriptive and correlational quantitative approach was applied with a non-experimental and transversal design. The study used an intentional non-probabilistic sample of 113 students in undergraduate psychology, public accounting and business administration programs that use a competency-based model at a private Colombian university. The outcome showed no significant differences among LS or in the frequency of ICT use in students with competency-based training. Additionally, the outcome showed a gender gap in which male students had the highest scores for the use of ICT.
\end{abstract}

KEYWORDS: LEARNING, HIGHER EDUCATION, COMMUNICATION TECHNOLOGY, INFORMATION TECHNOLOGY.

\section{INTRODUCTION}

Human beings live in a hyper-connected society in which three particular innovations have enabled major social transformations: the internet, online networks and mobile communication. First, the internet as a platform meets the needs and potentials of the contemporary human being, such as sociability and intellectual curiosity (Regis \& Vilchez, 2013). Online social and academic networks provide places where individuals participate in discussions and share information; finally, mobile communication, as a mediator of the social system, offers individuals the ability to communicate anywhere and anytime (Serrano-Puche, 2013). Information and Communication Technologies (ICT) are present in individuals' daily lives and have become so necessary that it is almost impossible to conceive of a world without them. These technologies are significantly transforming relationships and ways of understanding the world. In addition, they have contributed to collaborative work due to the ease of communicating in real time, blurring barriers of distance (Castells, 2015; Colina, 2008). Many universities worldwide are working to adapt to these social

*To whom correspondence should be addressed:

Universidad Cooperativa de Colombia

Complejo educativo la Julita

660003, Pereira, Colombia transformations by approaching the given conditions with greater flexibility to obtain the best results (Johnson, Adams-Becker, Estrada, \& Freeman, 2014).

Institutions of Higher Education (IHE) in Colombia have developed institutional policies that allow for the mainstreaming of ICT in academic structures in a significant way, generating an exponential development of knowledge and supporting formal and informal educational processes. This is proving to be highly motivating for students and is effective for achieving certain learning outcomes compared to traditional teaching processes that are based on print technology (Marin, Inciarte, Hernández, \& Pitre, 2017; Morales, Trujillo, \& Raso, 2015; Pallares \& Guerrero, 2015). The use of ICT creates powerful learning environments and transforms the learning and teaching processes, allowing students to face knowledge in an active, self-directed and constructive way (Agbo, 2015). ICTs are not considered simply substitutes for didactic strategies in the educational process; instead, they can be considered instruments that allow for the support of new ways of teaching and learning (Agbo, 2015).

Additionally, several Colombian universities have transformed their educational focuses from an objective-based model to a competency-based model, which is the most important element for achieving cultural integration, social mobility and productive development. This enables students to reach high educational levels and to obtain positive educational achievements in order to contribute to a more egalitarian society and to generate multiple individual, social and economic benefits (Brennan, Durazzi, \& Séné, 2013; Hopenhayn, 2003). Therefore, the levels of quality and coverage of undergraduate programs can be improved (Rodríguez-Albor, Gómez-Lorduy, \& Ariza-Dau, 2014).

An educational approach based on competency requires the development of mechanisms that transform the teaching-learning process. Teaching practices must offer contextualized training, eliminating gaps between the university and society (Unigarro, 2017); that is, teaching processes must be consistent with the reality of professional contexts (Gimeno-Sacristán et al., 2008). In short, evaluations must correspond to the pedagogical and didactic proposals that teachers carry out in order to reduce student dropout rates. This also positions educational institutions and universities to maintain high quality standards (Toro, 2012). In turn, the learning process aims for the development of competencies in the student such as being, knowing and doing; this objective allows for the integral development of the professional, focusing on their behaviors, knowledge and skills, respectively (Unigarro, 2017). 
In the competency-based educational model, increasing student performance is a challenge. This was addressed in this study by analyzing LS. Hence, the need to change the traditional teaching approach is emphasized in order to favor university training focused on students but with active participation of the teachers who will guide and supervise the learning process (Martín-García \& Rodríguez-Conde, 2009; Ortiz-Torres \& Aguilera-Pupo, 2005), thus allowing students to learn how to learn. This is a requirement of a permanent education, that is, an education for life (Biesta, 2015). Through the effective and efficient use of LS, the demands of the social context interact with the personal characteristics of the students (Aguilera-Pupo \& Ortiz-Torres, 2009; Hung, 2012; Wei, Moreau, \& Jennings, 2005).

In this sense, LS are understood as personal variables related to intelligence and personality that are expressed through different ways of approaching, planning and responding to the demands of the learning process (Camarero, del Buey, \& Herrero, 2000; Zatarain-Cabada \& Barrón-Estrada, 2011). These styles are relatively stable but can be adapted for teachers to use as a tool to understand how their students learn and thus modify or reinforce their own teaching approaches, which will positively impact student learning processes and, therefore, academic performance (Fernández, 2011; Maric, Penger, Todorovic, Djurica, \& Pintar, 2015; Pashler, McDaniel, M. Rohrer, \& Bjork, 2008).

At the same time, several Latin American and Caribbean studies on LS conducted in university environments (Garcia-Cué, Santizo, \& Alonso, 2008; Raposo-González, Barcia-Hernández, Negro-Álvarez, \& Fernández-Carballido, 2010; Ventura, 2011) concluded that the predominant theoretical approaches in the academy are those of Felder and Silverman (1988) and Alonso, Gallego and Honey (1995). From different angles, these theories show that the learning process is facilitated when the teaching style is favored by the student.

Note that multiple factors that have not yet been evaluated in a population of students through a competency-based approach may be related to LS and the use of ICT in university students. Therefore, the present work pursues two objectives: to determine the differences between LS and the use of ICT in university students within a competency-based model and to identify possible differences related to the frequency of use of ICT between genders.

\section{METHODOLOGY}

The present study uses a descriptive and correlational quantitative approach with a non-experimental, transversal design (Hernández, Fernández, \& Baptista, 2010). The sampling is non-probabilistic (Martínez-Bencardino, 2012) and was selected intentionally. The setting was a private Colombian university that uses a competency-based training model. The school administration voluntarily provided the students' information. A total population of 113 students was estimated and extracted from the psychology (16.8\%), public accounting $(57.5 \%)$ and business administration $(25.7 \%)$ programs. They were distributed from the first to the fifth school semesters.

The Honey and Alonso Learning Styles Questionnaire (CHAEA) was used for the evaluation of LS. This instrument consists of 80 statements presented as questions, with 20 corresponding to each of the LS: active, reflective, theoretical and pragmatic. The response system was dichotomous: the choices were agree or disagree. Affirmative answers are added up to obtain the total scores for each style. Finally, the scores were compared with the respective scales using a previous method (Escurra, 2011). This instrument has been widely used to measure LS (Rodríguez, 2006) and has demonstrated acceptable reliability and adequate measurement stability over time (Juárez-Lugo, 2014).

Likewise, the Questionnaire on the Use of Technologies, which was designed by Tobón, Arbeláez, Falcón and Bedoya (2010), was applied. This questionnaire consists of 18 items split into two subscales: use of information technologies and use of communication technologies. The response format is a five-point Likert scale with responses ranging from (1) "I do not know" to (5) "Most of the time". However, the questionnaire was adapted to the objectives of the present investigation, as the original was focused on teacher training. Therefore, its content validity was evaluated by expert judging, which suggested qualitative changes in the relevance of items 9 and 17. The internal consistency was measured by Cronbach's alpha and showed a reliability value of $\alpha=.714$.

\subsection{Procedure}

Initially, the project was presented to the research department of the university with the intention of requesting their approval and support for the present investigation. Then, the official database of the university community was requested to obtain the corresponding permissions for the application of the instruments. After the permissions were provided by the institution, the sample was selected. Finally, the instruments were applied with the collaboration of three students who had previously been trained to perform this task. Participation in the study was voluntary, and informed consent was obtained. Most of the students were evaluated in groups in their own classrooms each semester. The time allocated for the application of the questionnaires was approximately 20 to 30 minutes.

\subsection{Data analysis}

The data analysis was performed using SPSS v. 22. Frequency and percentage statistics were obtained. Student's t-test was used to compare independent samples, and an analysis of variance was performed for more than two factors. These parametric statistics were evaluated in agreement with the assumptions of normality (KS p > 0.05) and Levene's homoscedasticity. For the significant differences, Cohen's $d$ was estimated.

\section{RESULTS}

Table I describes the frequencies and percentages of LS by academic program. The results show that the most common style among students is the reflective style (33.6\%), followed by the theoretical style $(27.4 \%)$, pragmatic style $(23.0 \%)$ and active style $(15.9 \%)$. The reflective style is the most common style in psychology $(\mathrm{n}=11,57.9 \%)$ and business administration $(\mathrm{n}=10$, $34.5 \%$ ), while this figure is multimodal in the public accounting program, as the same number of students were found to have reflective, theoretical and pragmatic styles $(n=17,26.2 \%)$.

On the other hand, Table II shows that word processors ( $M$ $=4.82, S D=.38)$ had the highest scores among information technologies, followed by spreadsheets $(M=4.65, S D=.594)$ and access to digital sources $(M=4.37, S D=.77)$. The lowest scores were seen in the use of statistical packages $(M=1.71, S D$ $=.96)$ and video and sound processors $(M=2.99, S D=1.09)$. 
Table I. Descriptive data of LS according to academic program

\begin{tabular}{|c|c|c|c|c|c|c|c|c|}
\hline \multirow{3}{*}{ Type of LS } & \multicolumn{6}{|c|}{ Academic program } & & \\
\hline & \multicolumn{2}{|c|}{ Psychology } & \multicolumn{2}{|c|}{ Accounting } & \multicolumn{2}{|c|}{ Administration } & \multicolumn{2}{|c|}{ Overall } \\
\hline & $\mathbf{n}$ & $\%$ & $\mathbf{n}$ & $\%$ & $\mathbf{n}$ & $\%$ & $\mathbf{n}$ & $\%$ \\
\hline Active & 1 & 5.3 & 14 & 21.4 & 3 & 10.3 & 18 & 15.9 \\
\hline Reflective & 11 & 57.9 & 17 & 26.2 & 10 & 34.5 & 38 & 33.6 \\
\hline Theoretical & 5 & 26.3 & 17 & 26.2 & 9 & 31.0 & 31 & 27.4 \\
\hline Pragmatic & 2 & 10.5 & 17 & 26.2 & 7 & 24.1 & 26 & 23.0 \\
\hline Total & 19 & 100 & 65 & 100. & 29 & 100. & 113 & 100. \\
\hline
\end{tabular}

Table II. Descriptive statistics of ICT-Information

\begin{tabular}{lcc}
\hline \multicolumn{1}{c}{ ICT-Information } & MEAN & SD \\
\hline Word processors & 4.82 & .38 \\
Spreadsheets & 4.65 & .59 \\
Graphic processing & 3.56 & .84 \\
Video and sound processing & 2.99 & 1.09 \\
Multimedia presentations & 4.00 & .87 \\
Statistical packages & 1.71 & .96 \\
Video tutorials & 3.83 & .92 \\
Access to digital sources & 4.37 & .77 \\
\hline
\end{tabular}

Table III shows that the most common tools among communication technologies are chat platforms $(M=4.94, S D=.33)$ followed by email $(M=4.92, S D=.27)$. The least used are blogging platforms $(M=2.99, S D=.89)$ and wiki platforms $(M=$ 2.99, $S D=1.27$ ).

The descriptive analysis of the frequency of use of ICT in terms of gender (see Table IV) revealed significant differences. Male students had the highest scores in the use of information technologies $[\mathrm{t}(111)=2.412, \mathrm{p}=.018, \mathrm{~d}=0.50]$ and communication technologies $[\mathrm{t}(111)=3.133, \mathrm{p}=.002, \mathrm{~d}=0.50]$.

In the analysis of variance (Table V), no significant differences were found between the frequencies of use of information technologies $[F(110)=1.911, p=.153]$ and communication technologies $[F(110)=1.089, p=.340]$ in relation to the academic programs. Likewise, the descriptive analysis showed that students in business administration had the highest values for the use of ICT, followed by public accounting and then psychology students.
Table III. Descriptive statistics of ICT-Communication

\begin{tabular}{lcc}
\hline \multicolumn{1}{c}{ ICT-Communication } & M & SD \\
\hline Email & 4.92 & .27 \\
Chat platforms & 4.94 & .33 \\
Community participation & 3.60 & 1.19 \\
Video conferences & 3.16 & 1.07 \\
Discussion forums & 3.22 & .88 \\
Blogging platforms & 2.99 & .89 \\
Wiki platforms & 2.99 & 1.27 \\
Participation with learning & 3.20 & .98 \\
Construction of objects & 3.48 & .98 \\
Extended classrooms & 4.08 & .90 \\
\hline
\end{tabular}

Table IV. Gender and use of ICT

\begin{tabular}{lcccccc}
\hline \multirow{2}{*}{ ICT } & \multicolumn{2}{c}{ Men } & \multicolumn{2}{c}{ Women } & & $\mathbf{t}$ \\
\cline { 2 - 5 } & $\mathbf{M}$ & $\mathbf{S D}$ & $\mathbf{M}$ & $\mathbf{S D}$ & $\mathbf{( g l . 1 1 1 )}$ & $\mathbf{p}$ \\
\hline $\begin{array}{l}\text { Information } \\
\text { technologies }\end{array}$ & 31.0 & 3.3 & 29.4 & 3.2 & 2.412 & .018 \\
$\begin{array}{l}\text { Communication } \\
\text { technologies }\end{array}$ & 38.6 & 4.4 & 35.7 & 4.5 & 3.133 & .002 \\
\hline
\end{tabular}

Table V. Analysis of variance for ICT in academic programs

\begin{tabular}{|c|c|c|c|c|c|c|c|c|c|c|}
\hline \multirow{3}{*}{ ICT } & \multicolumn{6}{|c|}{ Academic programs } & & & \multirow{3}{*}{$\begin{array}{c}F \\
g l= \\
2,110\end{array}$} & \multirow{3}{*}{$\mathbf{p}$} \\
\hline & \multicolumn{2}{|c|}{ Psychology } & \multicolumn{2}{|c|}{ Accounting } & \multicolumn{2}{|c|}{ Administration } & \multicolumn{2}{|c|}{ Overall } & & \\
\hline & $\mathbf{M}$ & SD & M & SD & $\mathbf{M}$ & SD & $\mathbf{M}$ & SD & & \\
\hline $\begin{array}{l}\text { Information } \\
\text { technologies }\end{array}$ & 29.0 & 3.6 & 29.7 & 3.3 & 30.8 & 2.8 & 29.9 & 3.3 & 1.911 & .153 \\
\hline $\begin{array}{l}\text { Communication } \\
\text { technologies }\end{array}$ & 35.1 & 5.9 & 36.7 & 4.1 & 37.0 & 4.8 & 36.5 & 4.7 & 1.089 & .340 \\
\hline
\end{tabular}




\begin{tabular}{|c|c|c|c|c|c|c|c|c|c|c|}
\hline \multirow{3}{*}{ ICT } & \multicolumn{6}{|c|}{ Types of LS } & & & \multirow{3}{*}{$\begin{array}{c}F \\
g l=2,110\end{array}$} & \multirow{3}{*}{$\mathbf{p}$} \\
\hline & \multicolumn{2}{|c|}{ Active $(n=18)$} & \multicolumn{2}{|c|}{$\begin{array}{l}\text { Reflective (n } \\
\quad=38)\end{array}$} & \multicolumn{2}{|c|}{$\begin{array}{l}\text { Theoretical (n } \\
=31)\end{array}$} & \multicolumn{2}{|c|}{$\begin{array}{l}\text { Pragmatic (n } \\
=26)\end{array}$} & & \\
\hline & $\mathbf{M}$ & SD & $\mathbf{M}$ & SD & $\mathbf{M}$ & SD & $\mathbf{M}$ & SD & & \\
\hline Information technologies & 30.5 & 3.7 & 29.0 & 3.1 & 30.4 & 2.7 & 30.2 & 3.6 & 1.418 & .242 \\
\hline Communication technologies & 36.5 & 4.9 & 35.5 & 5.1 & 37.9 & 3.9 & 36.5 & 4.4 & 1.418 & .242 \\
\hline
\end{tabular}

Finally, the analysis of variance between the frequency of use of ICT and LS (Table VI) was not significant $[F(110)=1.418, p$ $=.242]$. Regarding the descriptive analysis, the data showed that students with the active $(M=30.5, E D=3.7)$ and theoretical $(M$ $=30.4, E D=2.7)$ styles made greater use of information technologies. At the same time, students with the theoretical style $(M=$ $37.9, E D=3.9)$ used communication technologies with a higher frequency.

\section{DISCUSSION AND CONCLUSIONS}

The relationship between LS and the use of ICT is an issue that university institutions and teachers are increasingly interested in addressing (Cuadrado-Gordillo, Fernández-Antelo, Monroy-García, \& Montaño-Sayago, 2013). Thus, the main objective of this work was to determine LS and the use of ICT in university students within a competency-based training model and to identify differences in the frequency of ICT use between genders. Therefore, it is necessary to emphasize that the most relevant finding is that men use ICT more, while the hypothesis of possible differences between LS and ICT use was not significant.

In this sense, the results show that the most common LS in university students within a competency-based model were the reflective and theoretical styles. It is noted that these students display abilities to logically analyze, reflect on and structure information, aiming for knowledge based on observations in a systematic and planned way (Alonso et al., 1995; Cuadrado-Gordillo et al., 2013; Raposo-González et al., 2010). In turn, some studies have suggested that LS predominantly depend on variables such as a student's context, the teaching strategies used by teachers and the curricular content of the different university degrees within the education system (Caballero-Pino, Norambuena-Paredes, Gálvez-Nieto, \& Salame-Coulon, 2015).

On the other hand, regarding the use of information technologies, it was found that the most common tools used by students were word processors (Word), followed by spreadsheets (Excel) and access to digital sources (search engines). Several other studies have also observed this trend. One study carried out with university students from Mexico concluded that word processors (Word) and multimedia platforms (PowerPoint) are the most common instruments for school presentations within the classroom, while spreadsheets (Excel) were used the least (López, 2007). Regarding the use of communication technologies, studies conducted with university students have shown that they use their computers to chat and exchange emails (Fernández \& Neri, 2013; Nweze, 2010). Therefore, it was established that these last two functions are used the most in higher education.

Given the association between the categories of LS and ICT use in university students with competency-based training, the outcome shows that students tend to be multimodal, since the active and theoretical styles present with greater associations with the management of information technologies, while students with the theoretical style use communication technologies more often (Shah, Ahmed, Shenoy, \& Srikant, 2013; Wilkinson, Boohan, \&
Stevenson, 2014). However, adopting predominant LS does not guarantee greater skills in the use of ICT, since the complexity of LS and the different ways of using ICT depends on individual factors and cognitive processes; thus, it can be affirmed that there are different ways of learning and implementing the use of ICT (Cózar-Gutiérrez, Moya-Martínez, Hernández-Bravo, \& Hernández-Bravo, 2016)

However, regarding the second objective, the literature supports the results of this research, that is, that men use ICT at a higher frequency. This is due to the tradition of the technological field being associated with the male gender (Fernández, Larraza, Ruiz, \& Maritxalar, 2008; Li \& Kirkup, 2007; Sanz, 2008). Nevertheless, a study carried out in Belgium with university students determined that there were no significant differences between men and women regarding the use of ICT in education. However, being a woman negatively impacted the use of ICT in leisure activities, since women perform different leisure activities. Likewise, in terms of gender, it is essential to consider the specific nature of the context and attitudes towards the use of ICT (Tondeur, Van de Velde, Vermeersch, \& Van Houtte, 2016).

This research indicates that business administration students use ICT at a higher frequency, followed by public accounting and then psychology students. Similarly, a study carried out at five Colombian universities established that there is a positive attitude towards the use of ICT among public accounting students, thus favoring the inclusion of ICT in academic curricula related to the economic and administrative sciences (Barreto-Carvajal, Cárdenas-Mora, \& Mondragón-Hernández, 2011). However, regarding psychology programs, a study carried out in Chile found that the vast majority of psychology students use ICT in their training programs, but this use is deficient, which prevents them from adopting the favorable conditions of the technological elements needed to facilitate the learning process (Muñoz, 2006).

However, future studies may clarify the relationship between LS and the use of ICT and complete a greater number of inferential analyses. Therefore, acknowledging some limitations of the present work will allow for new questions to be considered. First, the execution of research processes should be performed with greater methodological control over the cross-sectional nature of the measurements. Additionally, the variables regarding the use of ICT were obtained through a questionnaire on the use of technologies, which may cause bias through its questions. Therefore, a rigorous control of measurable indicators, such as monitoring the use of ICT, is desired. Finally, the representativeness of the sample should be considered. Addressing this could involve including a larger number of higher education institutions focused on competency-based training. These institutions are innovative in their educational processes and are experiencing slow growth at the national and international levels.

Finally, this is the first study to estimate the relationship between LS and ICT use in a private Colombian university with a competency-based training model. No significant differences were found between LS and the frequency of use of ICT in competency-trained students. In terms of gender, the results de- 
termined that women use ICT less frequently. Therefore, the main value of this work lies in the utility of the data collected for the proposal of actions aimed at improving the teaching and learning processes in this type of population.

\section{REFERENCES}

Agabo, I. S. (2015). Factors influencing the use of Information and Comunication Technology (ICT) in Teaching and Learning Comuter Studies in Ohaukwu Local Governament Area of Ebonyi State- Nigeria. Journal of Education and Practice, 6(7), 71-86.

Aguilera-Pupo, E., \& Ortiz-Torres, E. (2009). Las investigaciones sobre los estilos de aprendizaje y sus modelos explicativos. Journal of Learning Styles, 2(4), 22-35.

Alonso, C., Gallego, D., \& Honey, P. (1995). Los estilos de aprendizaje: procedimientos de diagnóstico y mejora (VI ed.). Bilbao: Ediciones Mensajero.

Barreto-Carvajal, O. M., Cárdenas-Mora, S. M., \& Mondragón-Hernández, S. A. (2011). Las tecnologías de información y comunicación en la formación de contadores públicos: análisis de uso y aplicaciones en cinco universidades colombianas. Cuadernos de contabilidad, 12(30), 243-272.

Biesta, G. (2015). What is education for? On good education, teacher judgement, and educational professionalism. European Journal of Education, 50(1), 75-87. doi:10.1111/ejed.12109

Brennan, J., Durazzi, N., \& Séné, T. (2013). Things we know and don 't know about the wider benefits of higher education: a review of the recent literature. London: Department for Business, Innovation and Skills.

Caballero-Pino, M., Norambuena- Paredes, I., Gálvez-Nieto, J. L., \& Salame-Coulon, A. M. (2015). Estilos de aprendizaje y rendimiento académico en estudiantes de Trabajo Social: un análisis entre México y Chile. Cuadernos de Trabajo Social, 14, 79-100.

Camarero, F. J., del Buey, M., \& Herrero F. J. (2000). Estilos y estrategias de aprendizaje en estudiantes universitarios. Psicothema, 12(4), 615-622.

Castells, M. (2015). Networks of outrage and hope: Social movements in the Internet age. USA: John Wiley \& Sons.

Colina, L. (2008). Las TIC en los procesos de enseñanza-aprendizaje en la educación a distancia. Laurus, 14(28), 295-314.

Cózar-Gutiérrez, R., Moya-Martínez, D., María, V., Hernández-Bravo, J. A., \& Hernández-Bravo, J. R. (2016). Conocimiento y uso de las Tecnologías de la Información y las Comunicaciones (TIC) según el estilo de aprendizaje de los futuros maestros. Formación universitaria, 9(6), 105-118. doi:10.4067/ S0718-50062016000600010

Cuadrado-Gordillo, I., Fernández-Antelo, I., Monroy-García, F. A., \& Montaño-Sayago, A. (2013). Estilos de aprendizaje del alumnado de psicopedagogía y su implicación en el uso de las TIC y aprendizaje colaborativo. RED. Revista de Educación a Distancia, 35, 01-19.

Cuellar, L. S., Cuellar, A. G., Muñoz, J., \& Herrera, P. (2016). Desarrollo de las TIC en la formación de recursos de enfermería semiescolarizada. In Memorias del XXIV Encuentro Internacional de Educación a Distancia. Guadalajara: Servicio de Publicaciones Universidad de Guadalajara.

Escurra, L. (2011). Análisis psicométrico del Cuestionario de Honey y Alonso de Estilos de Aprendizaje (CHAEA) con los modelos de la Teoría Clásica de los Test y de Rasch. Persona, 14, 71-109. doi:10.26439/persona2011.n014.253

Felder, R., \& Silverman, L. (1988). Learning and Teaching Styles in Engineering Education, Journal of Engineering Education, 78(1), 674-681.

Fernández, D., \& Neri, C. (2013). Estudiantes universitarios, TICS y aprendizaje. Anuario de investigaciones, 20(1), 153-158.

Fernández, N. (2011). Promoción del cambio de estilos de aprendizaje y motivaciones en estudiantes de Educación Superior mediante actividades de trabajo colaborativo en blended learning. Revista Iberoamericana de Educación a Distancia, 14(2), 189-208.

Fernández, V., Larraza, E., Ruiz, T., \& Maritxalar, M. (2008). Una aproximación a la situación de la mujer en los estudios universitarios de informática. Arbor, 184(733), 877-887.

Fraile-Calle, L. (2011). Estilos de Aprendizaje e identificación de actitudes y variables vinculadas al uso de las TICs en los alumnos de Enfermería de la Universidad de Salamanca. (Doctoral Dissertation, Universidad de Salamanca). Retrieved from https://gredos.usal.es/jspui/bitstream/10366/108966/1/ DTHE_Fraile_Calle_L_EstilosDeAprendizaje.pdf

García-Cué, J., Santizo, J., \& Alonso, C. (2008). Identificación del uso de la tecnología computacional de profesores y alumnos de acuerdo a sus estilos de aprendizaje. Journal of Learning Styles, 1(1), 168-185.

Gimeno-Sacristán, J., Pérez-Gómez, A. I., Martínez., J. B., Torres., J., Angulo, F., \& Álvarez., J. M. (2008). Educar por competencias, ¿qué hay de nuevo? Madrid: Morata.

Hernández, R., Fernández, C., \& Baptista, P. (2010). Metodología de la investigación. México: Editorial Mc Graw Hill.
Hopenhayn, M. (2003). Educación, comunicación y cultura en la sociedad de la información: una perspectiva latinoamericana. Chile: CEPAL.

Hung, Y. (2012). The effect of teaching methods and learning style on learning program design in web-based education systems. Journal of Educational Computing Research, 47(4), 409-427. doi:10.2190/EC.47.4.d

Johnson, L., Adams-Becker, S., Estrada, V., \& Freeman, A. (2014). NMC Horizon Report: 2014 Higher Education Edition. Austin, Texas: The New Media Consortium.

Juaréz-Lugo, C. S. (2014). Propiedades psicométricas del cuestionario Honey-Alonso de estilos de aprendizaje (CHAEA) en una muestra mexicana. Journal of Learning Styles, 7(13),136-154.

Li, N., \& Kirkup, G. (2007). Gender and cultural differences in Internet use: A study of China and the UK. Computers y Education, 48(2), 301-317. doi:10.1016/j. compedu.2005.01.007

López, M. C. (2007). Uso de las TIC en la educación superior de México. Un estudio de caso. Apertura: Revista de Innovación Educativa, 7(7), 63-81.

Maric, M., Penger, S., Todorovic, I., Djurica, N., \& Pintar, R. (2015). Differences in learning styles: a comparison of Slovenian Universities. Procedia-Social and Behavioral Sciences, 197, 175-183. doi:10.1016/j.sbspro.2015.07.079

Marín, F., Inciarte, A., Hernández, H., \& Pitre, R. (2017). Estrategias de las Instituciones de Educación Superior para la Integración de las Tecnología de la Información y la Comunicación y de la Innovación en los Procesos de Enseñanza. Un Estudio en el Distrito de Barranquilla, Colombia. Formación universitaria, 10(6), 29-38. doi:10.4067/S0718-50062017000600004

Martín-García, A. V., \& Rodríguez-Conde, M. J. (2003). Estilos de aprendizaje y educación superior. Análisis discriminante en función del tipo de estudios. Enseñanza, 21(0), 77-97.

Martínez-Bencardino, C. (2012). Estadistica y muestreo (XIII ed.). Colombia: ECOE Ediciones.

Morales, M., Trujillo, J. M., \& Raso, F. (2015). Percepciones acerca de la integración de las TIC en el proceso de enseñanza-aprendizaje de la universidad. Pixel-Bit. Revista de Medios y Educación, 46, 103-117.

Muñoz, M. (2006). Uso de tecnologías de información y comunicación en estudiantes de psicología. Nuevas Ideas en Informática Educativa, 4, 163-171.

Nweze, C. M. (2010). The use of ICT in Nigerian universities: A case study of Obafemi Awolowo University, Ile-Ife. Library Philosophy and Practice, 494. Retrieved from http://digitalcommons.unl.edu/libphilprac/494

Ortiz-Torres, E., \& Aguilera-Pupo, E. (2005). Los estilos de aprendizaje de los estudiantes universitarios y sus implicaciones didácticas en la educación superior. Revista pedagógica universitaria, 10(5), 1-9.

Pashler, H., McDaniel, M., Rohrer, D., \& Bjork, R. (2008). Learning styles: Concepts and evidence. Psychological science in the public interest, 9(3), 105119. doi:10.1111/j.1539-6053.2009.01038.x

Pallares, F., \& Guerrero, J. (2015). Problemáticas (contextos) a las que se enfrenta el docente para implementar las TIC en su práctica docente. Alternativas en Psicología, 18(31), 156-166.

Raposo-González, R., Barcia-Hernández, E., Negro-Álvarez, S., \& Fernández-Carballido, A. (2010). Los estilos de aprendizaje y su relación con las TIC en la adaptación al EEES de los estudios de farmacia. ARS Pharmaceutica, 51(3), 125-133.

Regis, D., \& Vílchez, L. (2013). Los jóvenes en la era de la hiperconectividad: tendencias, claves y miradas. Madrid, España: Fundación Telefónica

Rodríguez, J. (2006). Validación del CHAEA en estudiantes universitarios. Memorias, $7(1), 116-133$.

Rodríguez-Albor, G., Gómez-Lorduy, V., \& Ariza-Dau, M. (2014). Calidad en la educación superior a distancia y virtual: un análisis de desempeño académico en Colombia. Investigación y desarrollo, 22(1), 79-120.

Shah, K., Ahmed, J., Shenoy, N., \& Srikant, N. (2013). How different are students and their learning styles? International Journal of Research in Medical Sciences, 1(3), 212-215. doi:10.5455/2320-6012.ijrms20130808

Serrano-Puche, J. (2013). Vidas conectadas: tecnología digital, interacción social e identidad. Historia y Comunicación Social, 18, 353-364.

Sanz, V. (2008). Mujeres e Ingeniería Informática: el caso de la Facultad de Informática de la UPM. Arbor, 184(733), 905-915. doi:10.3989/arbor.2008. i733.233

Tobón, M. I., Arbeláez, M. C., Falcón, M. C., \& Bedoya, J. R. (2010). La formación docente al incorporar las TIC en los procesos de enseñanza y aprendizaje. Pereira: Universidad Tecnológica de Pereira.

Tondeur, J., Van de Velde, S., Vermeersch, H., \& Van Houtte, M. (2016). Gender differences in the ICT profile of university students: A quantitative analysis. Journal of Diversity and Gender Studies, 3(1), 57-77. doi:10.11116/jdivegendstud.3.1.0057

Toro, J. R. (2012). Gestión interna de la calidad en las instituciones de Educación Superior. Chile: RIL editores.

Unigarro, M. (2017). Un modelo educativo crítico con enfoque de competencias Colombia: Ediciones Universidad Cooperativa de Colombia. doi:10.16925/ greylit. 1833 
Ventura, A. C. (2011). Estilos de aprendizaje y prácticas de enseñanza en la universidad: Un binomio que sustenta la calidad educativa. Perfiles educativos, 33, 142-154.

Villa, A., \& Poblete, M. (2007). Aprendizaje basado en competencias. Bilbao: Universidad de Deusto.

Wei, Y. Z., Moreau, L., \& Jennings, N. R. (2005). Learning users' interests by quality classification in market-based recommender systems. IEEE Transactions on Knowledge and Data Engineering, 17(12), 1678-1688. doi:10.1109/ TKDE.2005.200

Wilkinson, T., Boohan, M., \& Stevenson, M. (2014). Does learning style influence academic performance in different forms of assessment? Journal of anatomy, 224(3), 304-308. doi:10.1111/joa.12126

Zatarain-Cabada, R., \& Barrón-Estrada, M. L. (2011). Herramienta de autor para la identificación de estilos de aprendizaje utilizando mapas auto-organizados en dispositivos móviles. Revista electrónica de investigación educativa, 13(1), 43-55.

How to cite this article: Barbosa Granados, S. H., \& Amariles Jaramillo, M. L. (2019). Learning Styles and the Use of ICT in University Students within a Competency-Based Training Model. Journal of New Approaches in Educational Research, 8(1), 1-6. doi:10.7821/ naer.2019.1.296 